\title{
The Symbolic Regionalism on The Architectural Expression Design of Kupang Town-Hall
}

\author{
Yohanes Djarot Purbadi ${ }^{1 *}$, Reginaldo Christophori Lake ${ }^{2}$, Fransiscus Xaverius Eddy Arinto ${ }^{3}$ \\ ${ }^{1,3}$ Universitas Atma Jaya, Yogyakarta, Indonesia \\ ${ }^{2}$ Universitas Katolik Widya Mandira, Kupang, Indonesia \\ 1*djarot.purbadi@uajy.ac.id, ${ }^{2}$ reginaldolake@unwira.ac.id, ${ }^{3}$ arinto56@gmail.com
}

Published: 31 December 2020

This study aimed to explain the synthesis design approach of the architectural expression in the Town Hall building of Kupang city. This is necessary due to the need for Town Halls, as public facilities, to reflect technically correct building standards, environment, and the aspects of political symbolism. Kupang Town Hall design uses the roof image expression of the Timor, Flores, and Sumba ethnic architecture in a harmonious composition and this means it is an example of an ethnic architectural synthesis in a modern building which represents a function, meaning, modernity, and local cultural identity. This research employed the social semiotics method to examine the design in relation to the surrounding social life context and the design was found to be produced from the symbolic regionalism approach which involved mixing the architectural images of Timorese, Flores, and Sumba ethnicities to modernize and conserve ethnic architecture and represent the cultural identity of East Nusa Tenggara. This, therefore, means architectural synthesis methods which are established on the symbolic regionalism approach have the potential to be used in designing public facilities in different places of Indonesia to reveal local cultural identities in modern buildings through symbolism based on an ethnic architectural image.

Keyword: Architecture expression, Ethnic architecture, Symbolic regionalism, Town-hall design 


\section{INTRODUCTION}

The technological revolution, especially digital technology, has changed global life towards integration and transformation (Skelton \& Allen, 1999) and this is reflected in the economy and urban restructuring and planning approaches based on information flows, and human perception of the future (Harrison, 1995). This means globalization has become the new worldwide reality experienced by all without an exception.

Globalization occurs in different human life dimensions and homogenization and cultural hybridity are some of the observable impacts (Rakhmawati, 2017). Meanwhile, the homogenization phenomenon is often referred to as universalization (Frampton, 1983) and this is important due to the obstacles usually faced by local culture to survive modernization in urban areas (Yuwono \& Wardiningsih, 2016). Moreover, globalization has changed the socioeconomic aspects, especially in the patterns of human work and life order (Perrons, 2004) and this is evident from the threat to the spatial structure and life of the Tambaklorok fishing community due to the gradual increase in sea level by $8 \mathrm{~cm}$ annually which threatens to drown the villages (Kristina \& Tyas, 2018).

Globalization related to the digital or technological revolution has several good and bad consequences on the economy, politics, culture, and several other aspects (Harwati, 2013) and also presents new challenges and hopes in the form of new economic, political, and cultural developments (Brysk \& Shafir, 2004). Moreover, global-local culture has also emerged after transformation due to the flow of globalization (Daryana \& Murwaningrum, 2018) and this subsequently leads to challenges and opportunities to grow and develop based on local wisdom (D Skillsi, Soemarno, \& Setijanti, 2015). Meanwhile, the regionalism movement in architecture is one of the developing phenomena responding to globalization and the desire to maintain local identity.

Regionalism is applied to urban spaces such as Kosovo where it aimed to elevate "regional modernism" to city landmarks (Jashari-Kajtazi \& Jakupi, 2017) and landscape architecture (Bowring \& Swaffield, 2004). The concept has also been applied to housing projects in Dacca (Haggerty, 2017) and Kharthoum (Bani, 2015). Public facilities in Singapore Conference Hall and Trade Union House were also reported to have been designed using a regionalism approach (Crinson, 2008). The same was found in tourist facilities in the form of a Meuble Centre in Juwiring to attract and support tourism (Khairanisa, Setyawan, \& Farkhan, 2017) as well as the Malang Ceramics Craft Centre (Silmi, Suparno, \& Paramita, 2017).

Regionalism is sometimes referred to as contemporary architectural terminology and the efforts to present individual and cultural identities have been reported in the contemporary architectural design of housing in Lahore (Malik \& Hassan, 2019) and Malaysia (Fatimah et al., 2018). The design is also expected to provide psychological satisfaction to occupants apart from its ability to reflect the cultural identities as seen in the Isfahan case in Iran (A. Sajad \& A. Sajad, 2016). Moreover, effort has been made to maintain the ancient principle of Vastu Shastra from India in Kashan, Iran to produce spiritual health for the residents (A. Sajad \& A. Sajad, 2016).

The concept of regionalism has been applied to several hotels in Yogyakarta using the culturalhistorical associative and local value-based critical regionalism approaches (Rohmawati et al., 2007). It has also been found in the hotels and spas design in Bali to fulfil international quality standards and create a Balinese identity (Adani, Suroto, \& Purwani, 2017). The concept was observed to be integrated into the design of worship facilities such as the traditional Acehnese architecture at the Bujang Salim Mosque in Krueng Geeukeuh (Dafrina, Purnama Lisa, Siska, \& Nurhaiza, 2017) and public facilities including Town Halls which certainly need to have certain architectural expressions.

Several studies have been developed and published in scientific journals on Town Hall architecture and this is majorly due to its need to fulfil certain requirements associated with the natural environment (Widodo, 2019; Subroto, 2019) and political symbolic expression (Michael, Hadjichristos, Bougiatioti, \& Oikonomou, 2010). In terms of the spatial layout, the design also needs to consider end-user aspects (Valand, 2011) including the ergonomic (Holden \& Valdez, 2019), acoustic (Marshall \& Hyde, 1982), natural lighting (Balocco \& Frangioni, 2010), and space conditioning (Voll \& Seinre, 2012).

A Town Hall requires an outer space arrangement to support its status as a public facility and also 
need to reflect its function and symbolism visually and spatially (Cirkovic, 2016 and Khelifa-Rouaissia \& Boulkroune, 2017). In the historical perspective, it is important to consider a Town Hall as part of architectural heritage (Kuśnierz-Krupa, Figurska-Dudek, \& Malczewska, 2019) architectural conservation in its design has been reported to require a crossdisciplinary approach (McHugh, 2020). The Aceh Governor's Office in Lhokseumawe even adopted the traditional Acehnese architecture as part of the architectural regionalism approach (Nurkarismaya, Siahaan, \& Eddy, 2020).

This research, therefore, examined the architectural expressions in the Town Hall design at Kupang, East Nusa Tenggara province which uses roof elements from three ethnic architectures including Timor, Flores, and Sumba. This was based on the context that the East Nusa Tenggara has different ethnicities which require the architectural design of the Town Hall to be the pride of its multi-ethnic citizens. Moreover, the underlying architectural approach which is the symbolic regionalism used in the architectural expression synthesis of the Kupang Town Hall was also analysed.

\section{Regionalism in architecture}

Architectural regionalism was developed as a response to the challenges faced at a particular time and the concept has received great attention since 1980 (Eggener, 2002) but observed to have faded starting from 1990 (Moore, 2007). A new regionalism was developed in 1990 in response to globalization (Peterson, Mcalpine, Ward, \& Rayner, 2007) and known as the critical regionalism in architecture which was basically intended to encourage a dialectic of universal civilization with national culture (Crinson, 2008). Its impact was experienced in urban spatial design and architectural landscape in the form of contemporary architectural designs (Lefaivre \& Tzonis, 2004). It is, however, important to note that regional identity or regionality is a character while regionalism is the approach or method used to produce it (Maria Immaculata Hidayatun, Prijotomo, \& Rachmawati, 2012).

The essence of regionalism is to respond to the architectural homogenization caused by the modern architectural movement while promoting the mediation of universal civilization and local culture (Paiva Henrique, 2013). It is also considered a criticism of modernism (Pour, 2015) based on its effort to connect the past with the present using unique products related to certain places, cultures, and climates (Yang, 2009). Regionalism is seen as a way of synthesizing modern culture with individualistic elements in local culture (Botz-Bornstein, 2016) and also considered to correct the sterility and abstraction of modern architecture by displaying the strength of the local context, needs, and potential (Bahga \& Raheja, 2019).

Regionalism is in a certain sense associated with climate due to the belief in the strong support of "environmentalism" in the form of "ecological architecture" to the concept of critical regionalism (Poon, 2019) and this is evident in the "tropical regionalism" developed and pioneered by Ken Yeang (Yeang, 1987). It is also recently closely associated with sustainable development through the bioclimatic approach (Olgyay, 2015) and also related to the need to adapt architecture to climate based on belief (LE, 2018).

Another version of regionalism is closely associated with the local community spirit in order to produce an architectural design which expresses this spirit (Hibbard, Mason, \& Weitze, 2010). For example, the Youth Centre facility in Magelang is designed with a critical regionalism approach to express the younger generation spirit (Arifah, Singgih, \& Marsudi, 2017). Moreover, the experience in India shows the ability of this concept to produce architectural works with a strong character (Bahga \& Raheja, 2018) due to the capability of the critical regionalism to raise the opportunity and universality values in the works produced at the same time (Maria I Hidayatun, Prijotomo, \& Rachmawati, 2013) as a counterweight to universalization in the globalization era (Crinson, 2008).

The regionalism founded on ethnic architecture has become a separate trend in Indonesia with some seeing "archipelago architecture" as the basis for the formation of "Indonesian Architectural Regionalism" (Maria I Hidayatun, Prijotomo, \& Rachmawati, 2014) while some believe "local architecture" spread throughout Indonesia is the Mother Earth (Ibu Pertiwi) for architectural works created now and the future (Purbadi, 2010). The interpretation of ethnic architecture elements was typically used as an alternative to developing critical regionalism (Maulana \& Suswati, 2014; Tuan, Song, Truong, Verne, \& Innovantes, 2019). Moreover, the aspects of tangible and intangible elements in architecture such as positive feedback from the 
space user or observer are very useful in design (Azmi, Harumain, Ali, Zaini, \& Abdullah, 2017) and are particularly aesthetic when elements originate from precedents (Shahedi, 2012).

Regionalism focuses on the roof image of ethnic architecture as an alternative to be considered due to its importance to the Indonesian ethnic architecture. It is, however, important to define the ethnic architecture as the right terminology used in describing the architecture developed among ethnic groups throughout Indonesia (Purbadi, 2019) while the regionalism in the country is expected to be based on the Bhinneka Tunggal Ika philosophy (Maria I Hidayatun, 2018) in line with the concept of elevating nationalism (Spivak, 2014). There is, in fact, a view which considers Mangunwijaya's concept of Wastu Citra as a regionalism local wisdom in the Indonesian architecture (Loanoto, 2019).

The observation of regionalism phenomenon in Indonesia has shown at least two categories which are mimetic and symbolic. The mimetic regionalism is the architectural design which takes and attach ethnic architectural elements directly into designs characterized by modern architecture. It focuses more on the visual aspects suitable to be combined with modern architectural styles without considering the meaning and values underlying the adopted ethnic architectural elements. This means the substance used is limited to tangible ethnic architectural elements such as the appearance, structure, ornaments, and landscape layout.

Symbolic regionalism is different due to its establishment on the critical approach which considers the original value and meaning of the ethnic architectural elements used in the design to produce modern designs while simultaneously transmitting local identities. The elements are managed intelligently in such a way that the architect incorporates the elements of modern culture and also maintain the original meanings and values. This, therefore, means the composed substance is an intangible element from an ethnic architectural element which focuses on the value and meaning aspects.

\section{MATERIALS AND METHODS}

The architectural discourse in Indonesia has been circling traditional architectural themes which is a synthesis of traditional architecture with European styles as well as the architecture influenced by modern or international architecture (Salura, Clarissa, \& Lake, 2020a).

This study included one of these themes which is the determination of the relationship between ethnic and modern architectures using the architectural design of the Kupang Town Hall inaugurated in 1996 to coincide with the anniversary of the Kupang City as the research object (Lake et al., 2020). An interesting aspect of the Town Hall design is its architectural expression as indicated by the roof from Timor, Flores, and Sumba ethnic groups in one building which makes it an important attribute. Meanwhile, the building also reflects modern architectural design patterns which tend to have strong symmetrical aspects. This combination of ethnic elements and modern architecture, therefore, indicates a regionalism approach.

Figure 1 shows the three architectural roofs are joined together with one straight line to strengthen the symmetry of the Town Hall architecture while the round roof at the bottom is joined by a rectangular roof in the middle and later peaks at the top with a rectangular roof and a tower character. There is also a strong sense of verticalism which is balanced with horizontalism in a strong symmetrical arrangement. The Town Hall building generally has strong monumentalism characterized by modern architecture and clearly expresses the cultural identity of East Nusa Tenggara at the same time.

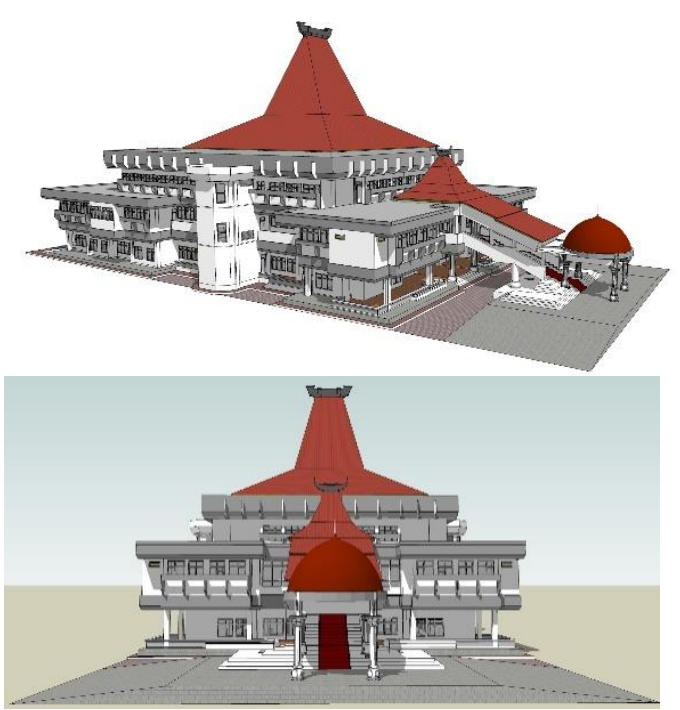

Figure 1: Three-dimensional Image View (above) and Front View (below) of Kupang Town Hall. Source: (Lake et al., 2020) 
The roof structure of the Town Hall is in a linear order but has a hierarchy through the use of the floor height. The lowermost roof was also observed to be arranged based on circular geometry even though the plan is rectangular and the second and third roofs above are built using the rectangular geometry. This aesthetically means the geometric composition includes a circle, a rectangle, and a larger rectangle and they are all directed towards creating a consistent symmetry in the building with the centre as the main point of interest for the overall mass.

Cultural references are an important element in architecture as observed in the round roof of ethnic Dawan architecture which is used as an umbrella element in the ground floor space or the entrance to the Town Hall building. The Flores house roof is placed above the building and used as the umbrella for the second-floor space while the third top roof with a rectangular geometric base derived from the Sumba ethnic architecture covers the third-floor space. These three shapes are composed by considering the threedimensional geometric harmony to produce a harmonious composition. Meanwhile, the front view is consistently symmetrical and the side view shows a height difference which represents the hierarchical composition of the aesthetics.

The Kupang Town Hall design generally shows the ability of the ethnic architectural elements to compose with modern cultural elements towards producing modern architectural works with local identity. The design also reflects the Town Hall geometry indicates the inner spatial arrangement characterized by a rectangular geometry which functions as public service offices in the form of multi-storey buildings and this is the evidence of architectural modernity. Meanwhile, the building roof created from the three ethnic architectures of East Nusa Tenggara is an important feature of the local identity disclosure which is the cultural representation of the area.

The semiotic-social method was used in this research (Van Leeuwen, 2005) to examine the semiotics phenomenon in people's lives by interpreting the roof shape and location of the Town Hall in relation to the use of roofs in the socio-cultural context. The research made an effort to connect signs and also to determine the function and the meaning and value in a social context. The method also disclosed the background of the sign utilization by showing the external factors influencing the users and this level required the deep development of semiotics into social semiotics which sees the sign phenomenon as part of people's lives. The process of critical-interpretation in social semiotics also indicate signs and characteristics of the regionalism approach.

\section{RESULT AND DISCUSSION}

\subsection{Symbolic architectural expression at the Kupang Town Hall}

Modern expressions and local symbols are the main impressions of the Kupang Town Hall design and the architectural elements are uniquely related to the roof shape. Three ethnic roof images including the lopo building from Timor, Sa'o from Flores, and the tower from Sumba (Lake et al., 2020) were used in the hall in an attempt to represent the form, meaning, and value of ethnic architecture. This effort is considered natural due to the fact that the roof is one of the most prominent features of ethnic architecture in Indonesia.

The front roof was obtained from the lopo (barn) in Timor (Dawan) and the elements of the ethnic group is also reflected at the front of the Town Hall. It is important to note that the Dawan tribe is the largest ethnic group on Timor Island and this is observed in the Kupang Town Hall. For example, the Lopo in Kaenbaun village is an important building related to the local concept of "women and men" (feto-mone) which are eternal fundamental elements used in creating life (Purbadi, 2010) and observed to be very similar to the Yin-Yang concept in Chinese culture. The Lopo is, therefore, essentially a men's room (mone) or an outside place for men or neighbours to gather (Purbadi, 2017).

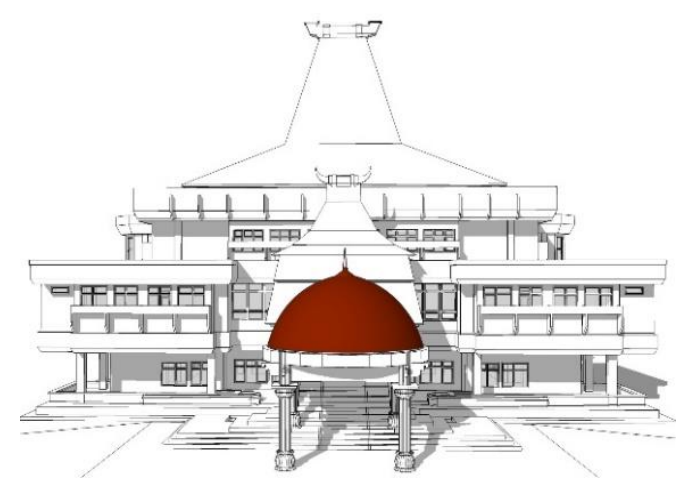




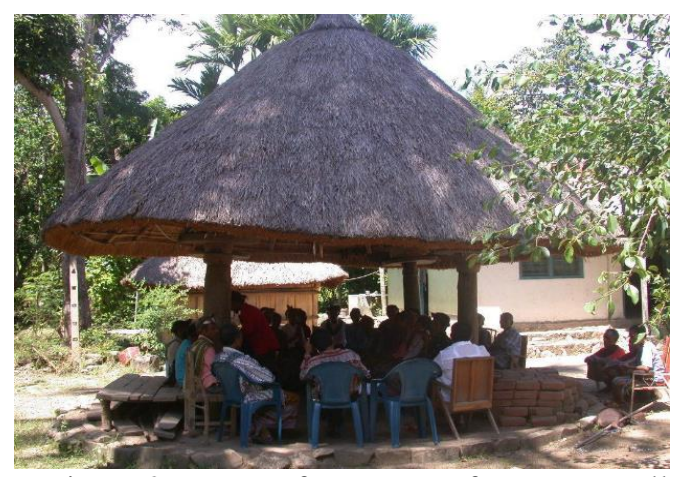

Figure 2: Image of a Lopo roof at Town Hall Kupang (above) and Lopo Tolas Kaenbaun from Kaenbaun Village (below); Source: above (Lake et al., 2020) and below (Purbadi, 2010)

In line with the aspect of the roof shape, the lopo is built with a rectangular geometry on the plan and the curvature on the roof. The rectangular plan involves the use of columns on the four lopo corners to create a space under the curved roof which is a meeting room with a rectangular pattern, a curved roof, and a halabena or thick and long planks which is usually in 4 pieces placed between columns and around the midpoint. Moreover, household utensils such as the three types of mortars for pounding rice, corn, and chillies are mostly found in the space (Purbadi, 2010).

In line with the aspect of the traditional function, lopo is an open space to welcome guests either from the garden, a neighbour's house, or someone passing on the road. In the tradition of Timor villages in the past, the living room of this modern era was not existing due to the existence of only two building typologies which are the lopo and roundhouse. The lopo is placed as the front or outside room while the roundhouse (umebubu) is behind or inside and this means the adoption of lopo as a roof at the Kupang Town Hall is to depict being in front, openness, and presence which are suitable for the Town Hall entrance.

Based on the aspect of meaning, lopo is a building for men as well as a living space and a place for men to meet. It is usually located at the front of the house in the Dawan tradition and serve as the guardian of the roundhouse (umebubu) which is located nearby (Purbadi, 2010). Furthermore, lopo means the front room which serves as a link between the inner zone of a house and the outside. This means it is a living room in modern architecture where residents meet with people from the outside.
These interpretations showed the approach used is not merely a "copy and paste" of ethnic architectural elements but a critical evaluation of the original values and meanings analysed, discussed, and adjusted to modern situations. Moreover, the intangible substance aspect of the reference serves as an important function for the design in critical thinking-based regionalism and this involves the maintenance of the original values and meanings of the ethnic architectural elements using modern elements. The symbolic expression also makes use of modern elements such as the structural, construction, and material technology and this further indicates the application of a symbolic expression method.

The middle roof is the $S a^{\prime} o$ from the Lio village in Ende, Flores which is one of the typical houses building in the Lio tribe community at the Wologai traditional village (Ch. Lake, 2016). It is generally stilt buildings or a floor raised above the ground and the number in the Wologai traditional village was found to be 20 units with each used for different traditional ceremonies due to the variations of the rituals and the need to represent the lineage of the Lio people living in customary villages. The same phenomenon was observed in Sumba, especially in the main village, with the buildings which form the traditional villages found to be tribal houses (kabisu) erected to be facing each other around an open or field (Purbadi, 2018).

In line with the aspect of shape, the $S a^{\prime} o$ roof shows a two-point pyramid shape with a rectangular floor plan and several attempts have been made to transit from a circular to a rectangle base plan with the top of the roof point changed to the roofline from the perspective of its relation with lopo. These efforts are reasonable due to the increase in the width of the building and the subsequent need for a rectangular geometric space and this geometrically means there is a controlled change in relation to the creation of a continuous and naturally interconnected space.

Based on the function aspect, the $\mathrm{Sa}^{\prime} \mathrm{o}$ roof serves as a sacred and social building (Ch. Lake, 2016). It is traditionally a place of ritual for tribal people and those with the same blood or descent and also serves as a meeting place for them to negotiate or discuss matters related to the lives of residents, tribes, and the whole village (Ch. Lake, 2016). This functions of $S a^{\prime} o$ are similar to those of the kabisu house in the Sumba tradition at the main village which represents the tribes in the structure of the customary community (Purbadi, 2018). 


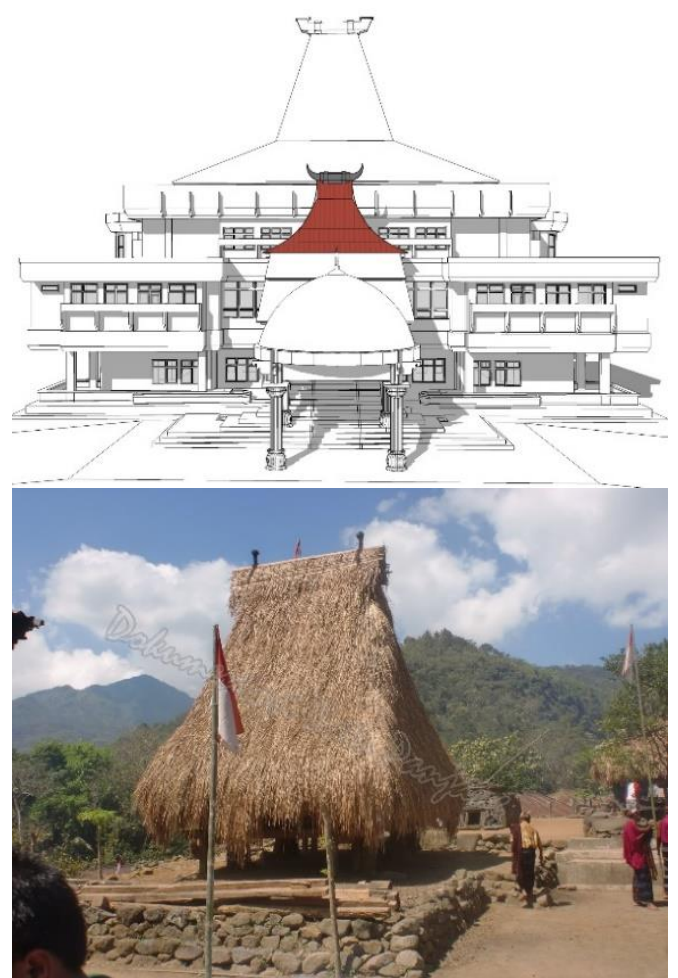

Figure 3: Roof images of the Sa'o Keda (above) and $\mathrm{Sa}^{\prime} \mathrm{o}$ Keda from Wologai village (below); Source: above (Lake et al., 2020) and below

(Ch. Lake, 2016)

In line with the aspect of meaning, the $S a^{\prime} o$ building represents the tribe in the traditional village (Ch. Lake, 2016) and has close blood, social, and religious ties with the tribesmen. It is a place of orientation for families in a village and its presence indicates the existence of every tribe and family. Therefore, the use of $S a^{\prime} o$ as an element in the Kupang Town Hall design directly indicates the symbolism of the involvement of tribes in public facilities as represented by the image expression of the $S a^{\prime} o$ roof.

The interpretation showed the approach used is not a "copy and paste" of ethnic architectural elements in the modern office building of the Town Hall in Kupang but rather involves critical thinking on the original values and meanings which were later then raised and adapted to modern situations. Moreover, the intangible substance aspect of the reference serves as an important function for the design in critical thinking-based regionalism and this involves the maintenance of the original values and meanings of the ethnic architectural elements using modern elements. The symbolic expression also makes use of modern elements such as the structural, construction, and material technology and this further indicates the application of a symbolic expression method.

The top or highest roof observed from the image of the architectural roof shape in the Sumba house belongs to the Rato's house in Galubakul Traditional Village, Central Sumba which is a sub-part of the Laitarung Traditional Village located on a hill (Purbadi, 2018). The Sumba culture has the traditions of "primary village" and "secondary village" as observed in Kaenbaun (Purbadi, 2010) and its architectural tradition defines the highest roof in the traditional village house as the Rato which means the village leader. This roof also has one holy pillar with a special Mayela wood (Purbadi, 2018) and a secondary village are expected not to have roofs exceeding those in the primary village.
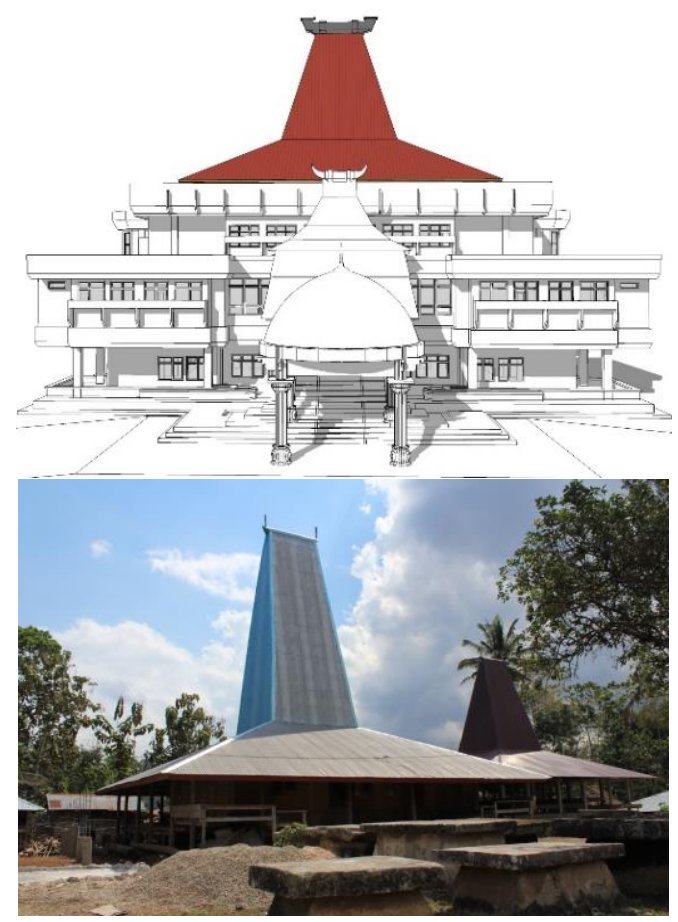

Figure 4: Roof image of Sumba's house tower (above) and the Rato's house tower from Galu Bakul village, Central Sumba (below).

Source: above (Lake et al., 2020) and below (Purbadi, 2018)

The aspect of the highest roof shape showed the Kupang Town Hall looks like a tall tower and its roof was observed to be geometrically symmetrical and based on a rectangular plan geometry which is the basis for the plan formation in the Sumba tradition. This plan is used in creating a residential layout which emphasizes 
the living room and extends to other four winds which are the vestibule, backroom, left room, and right room. Moreover, the living room with the tower roof serves as a family fireplace room and also as a sacred family kitchen (Purbadi, 2018).

The function aspect traditionally shows the tower roof as the upper room and the third part (uma deta) in the space concept of the Sumba ethnic house which is followed by the human space (uma dei) and bottom space for animals (uma kambunga) (Tanrim, Stefani, Cynthia, Stefanie, \& Wijaya, 2014). The highest part (uma deta) in the form of a tower is a sacred space for living marapu, ancestors, and to store family assets and heirlooms (Purbadi, 2018). The existence of this tower roof is another visual function considering its quite prominent height.

The meaning aspect shows the tower roof is a sacred space or the world above in the spatial thinking of the Sumba house (Purbadi, 2018). The shape, location, and height indicate the existence of space higher than humans which are on the 2nd floor and animals on the ground floor. The tall and conical tower conveys the meaning of a sacred space ruling over people and animals in the world and the existence of marapu, ancestors, and family heirlooms signify its sanctity (Purbadi, 2018).

These interpretations show the approach used was symbolic regionalism which emphasizes the original value and meaning rather than the form. Moreover, the traditional values and meanings were formulated, selected, and adjusted to the modern situation and expressed symbolically using a fixed form, position, and meaning. This means the design approach prioritizes the value and symbolism of the roof element as a reference.

\subsection{Roof image as a symbolic element in ethnic architecture}

The roofs on residential buildings in ethnic communities are an important element and contain cultural significance. For example, the roof of the Sasadu traditional house including the big and musyawarah houses in the Jailolo community of West Halmahera reflects the community's philosophy of life (Wakim, 2018). Moreover, roof shape has become an important indicator of the tribal identity related to the ethnic distribution among the Bakumpai Dayak tribe (Mentayani, 2008) and the distinctive roof shape in the limas house in Palembang also shows the civility of the indigenous people with courtesy (Rakhman, 2015). The roof is also the identity of the Malay ethnic architecture for the Majo Kampar tribe (Faisal, 2019) and san important element in the preservation of the traditional housing environment for the Using community, Kemiren village, Malang (Nur, Antariksa, \& Sari, 2009).

It is important to understand the reasons for the selection of Timor, Flores, and Sumba roof as an important element in the Kupang Town Hall design. There are three major islands in the East Nusa Tenggara Province and they are Timor, Flores, and Sumba and since Kupang is the capital of the province, there is a need for adequate representation in its cultural system, including the architectural design and this was achieved through a mixed culture approach using the elements of ethnic culture. Therefore, it was only natural to select the architecture of these three islands to represent the East Nusa Tenggara identity as expressed in the Kupang Town Hall design.

The roof is an important element in the ethnic architecture design and has become a volatile architectural element due to the influence of technology, resources, economic, social, and cultural conditions at a time (Aswati, 2018) as well as the potential to design a roof based on cultural acculturation intentions. The roof observed in the architectural tradition of Timor, Flores, and Sumba have a unique geometric shape according to local traditions with the lopo roof in Timor adopted from the roundhouse with a geometric shape which blends like a man and a woman while the rectangular roof and top discovered in the form of a line in Flores and Sumba convey show the living room is an important space.

The roof in the architectural culture of Timor, Flores, and Sumba represents the crown of the house buildings and also considered an important and sacred part of the head (Purbadi, 2018). Its function as a head or crown is a major architectural element with the head representing the world above or sacred heaven. The ethnic tradition of East Nusa Tenggara believes the sacredness of space is always represented in the form of building elements including the roof which is the expression of the traditional thoughts in symbolic terms. 
The image of a simple roof is shown in the ethnic architecture of Timor, Flores, and Sumba with the towering roof considered part of the architectural aesthetics while the upward space or orientation is one of the important concepts in East Nusa Tenggara culture. Moreover, the ancestors living in heaven and homes are symbolized using the roof and the surrounding space (Purbadi, 2018). Sacredness is one of the values required to be expressed in ethnic architecture and this is expected to be present in the Kupang Town Hall in order to demonstrate a sense and respect for the sacred eternal world. Furthermore, representation and presence are important traditions in society such as the presence of all tribesmen in a ceremony initiated to renovate the tribal house in Kaenbaun village (Purbadi, 2010).

The symmetrical roof image is a tradition discovered throughout the ethnic architecture of the East Nusa Tenggara region. The middle axis is important in the house spatial layout to form the front, middle, and rear spaces which also presents the three known worlds which are the underworld, middle world, and upper world (Purbadi, 2018). This spatial arrangement was found in the geometric design pattern at the Kupang Town Hall with the symmetry essentially observed to be marking the simple thoughts of ethnic communities which tend to use traditional classifications such as top-down, inside-outside, left-right, front-back, old-young, and malefemale (Purbadi, 2010).

\subsection{Symbolic regionalism}

The roof design of the Kupang Town Hall is simply a synthesis or mixture of the techniques used in laying the three ethnic architecture roofs parallel to each other. Three copies of the roof image from the three ethnic architectures were selected due to the need to use the precedents and references in the cultural area of East Nusa Tenggara. Diversity is a form of wealth in Indonesian architecture (Nurdiah \& Hariyanto, 2013) and this means it is very meaningful when applied in new buildings. This is in line with a previous study which showed architectural imagery as a precedent with the potential to be a substantial reference from the observer's perceptive (Shahedi, 2012). Moreover, ethnic representation is important to the East Nusa Tenggara community culture to recognize and respect the existence of different tribes within the same province.
The Kupang Town Hall design was observed to have an ethnic architecture image reflected through the roof shape and those selected as the dominant form in the design are discovered to be in line with the appropriate symbolic action. The image answers the monotonous aspect of modern building expression and also serve as the method to preserve local architectural heritage (Salura, Clarissa, \& Lake, 2020b). Moreover, local architecture is believed to be the basis for the architectural regionalism development in Indonesia (Maria I Hidayatun et al., 2014) and archipelago architecture has been reported to be the Mother Earth for present and future architecture (Purbadi, 2019).

The use of local architectural elements through roof forms is a method to show the cultural heritage value and meaning of ethnic architecture adapted to the times or zeitgeist (Salura et al., 2020b). New architectural works are expected to have local cultural characteristics and identities to appreciate and respect the preceding generation. Moreover, the application of vernacular architectural elements also shows the potential for transformation from vernacular to modern architecture (Malik \& Hassan, 2019).

The ethnic architectural roofs applied also indicate respect for the ethnic culture. It is important to note that hybrid architectural phenomenon involves mixing modern and local elements and some of the ethnic architecture developed in Indonesia is one of the important references of the emerging hybrid architectural works. A monumental example is the ITB campus hall with a traditional roof (Salura et al., 2020b) or the campus headquarters building at Gadjah Mada University.

The mixture of roof images is also a method to combine values and meanings in hybrid architecture observed to be developing in East Nusa Tenggara but the application of three roof images in ethnic architecture was considered to be relatively new. Architects have adopted roof as an aesthetic-symbolic element from only one ethnic architectural variety as observed in the use of Town Hall buildings as places of worship. Therefore, the three ethnic architectures applied are said to be a unique method in East Nusa Tenggara to respect the presence of important parties (Purbadi, 2010) and this tradition of representation through symbolic elements has been entrenched in the community. This means the adoption of the ethnic architectural elements 
as part of the process to respect different parties in the Kupang Town Hall design is natural.

The geometric hierarchy of the roof from round to square showed the symbolism and aesthetics of the composition. The symbolism aspect indicated a similarity in the meaning of ethnic architecture transferred directly to the Town Hall hybrid architecture with the lopo described as a receiving room and an entrance in the minds of those seeing the roof at the Hall. This same is expected to happen with the Flores and the Sumba tower roof with the height indicating the existence of an important space within the building.

\section{CONCLUSION}

The architectural expression at the Kupang Town Hall visually indicated with the row of three ethnic architecture roofs from Timor, Flores, and Sumba is an intelligent and harmonious architectural synthesis. It is able to satisfy the need for architectural modernization and conversation of ethnic architecture which represents the existence of multi-ethnic parties in the study area. This means the selection of ethnic architecture elements was recognized as the key to express the recognition of the multi-ethnic society in East Nusa Tenggara.

The Kupang Town Hall design is an example of an architectural synthesis designed using an ethnic architecture with a symbolic regionalism approach. Certain ethnic elements were selected in the framework of representation through the roof packaged in an image expression based on the awareness of their value and meaning after which they were intelligently adopted and composed. Therefore, the adoption of the three roofs was based on an understanding of their values and meanings.

The symbolic regionalism approach was discovered to have the potential to design public facilities with architectural symbolism and modernism in different places of Indonesia based on local architectural images. This approach has the ability to preserve the local architecture and adapt to the spirit of the times or zeitgeist through the use of creative and innovative strategies. It, however, becomes, more effective with the support of the semiotic-social thinking framework which is able to explain the value and meaning of a physical element in the original context of the owner's community life.

\section{REFERENCES}

A. Sajad, R., \& A. Sajad, S. (2016). Responding Human Needs in Iranian Traditional Houses in Psychological Approach (Case study: Haghighi House, Isfahan, Iran). Journal of Design and Built Environment, 22-29. https://doi.org/10.22452/jdbe.sp2016no1.3

Adani, S., Suroto, W., \& Purwani, O. (2017). Hotel Spa Internasional Di Bali Dengan Pendekatan Arsitektur Regionalisme. Arsitektura, 14(2). https://doi.org/10.20961/arst.v14i2.9064

Arifah, R. A., Singgih, E. P., \& Marsudi, M. (2017). Youth Center Dengan Pendekatan Arsitektur Regionalisme Di Kabupaten Magelang. Arsitektura, 13(2). https://doi.org/10.20961/arst.v13i2.15658

Aswati, Z. P. (2018). Transformasi Atap Masjid Raya Bandung. Seminar Ikatan Peneliti Lingkungan Binaan Indonesia (IPLBI), A533-A538.

https://doi.org/10.32315/sem.1.a533

Azmi, N. F., Harumain, Y. A. S., Ali, A. S., Zaini, S. F., \& Abdullah, M. F. (2017). Characterdefining elements of shophouses buildings in Taiping, Perak. Journal of Design and Built Environment, 17, 139-149. https://doi.org/10.22452/jdbe.sp2017no1.12

Bahga, S., \& Raheja, G. (2018). An account of critical regionalism in diverse building types in postcolonial Indian architecture. Frontiers of Architectural Research, 7(4), 473-496. https://doi.org/10.1016/j.foar.2018.09.001

Bahga, S., \& Raheja, G. (2019). A study of regional assertions in the architecture of Delhi from the 1970s to the present. Buildings, 9(5). https://doi.org/10.3390/buildings9050108

Balocco, C., \& Frangioni, E. (2010). Natural lighting in the Hall of Two Hundred. A proposal for exhibition of its ancient tapestries. Journal of Cultural Heritage, 11(1), 113-118. https://doi.org/10.1016/j.culher.2009.02.005

Bani, O. M. (2015). Critical regionalism: studies on contemporary residential architecture of khartoum-sudan. Architects' 4th Scientific Conference, (Towards Sustainable Urban Development).

Botz-Bornstein, T. (2016). Transcultural architecture: The limits and opportunities of critical regionalism. In Transcultural Architecture: The Limits and Opportunities of Critical Regionalism. https://doi.org/10.4324/9781315550220

Bowring, J., \& Swaffield, S. (2004). Think Global, Think Local: Critical regionalism and 
Landscape Architecture. Landscape Review, 9(2), 1-12.

Brysk, A., \& Shafir, G. (2004). People out of place: Globalization, Human Rights, and the Citizenship Gap. In Ebook. https://doi.org/10.4324/9780203643983

Ch. Lake, R. (2016). Budaya Tektonika Wologai Ende, Nusa Tenggara Timur; Sebuah Seni Berkonstruksi Rumah Adat Desa Wologai Tengah, Kecamatan Detusoko, Warisan Leluhur Wawo - Ata Lio di Bawah Kaki Gunung Lepembusu. ATRIUM - Jurnal Arsitektur, $1(2)$. https://doi.org/10.21460/atvm.2016.12.15

Cirkovic, E. (2016). Architecture of Sovereignty: Bosnian Constitutional Crisis, the Sarajevo Town Hall, and the Mêlée. Law and Critique, 27(1), 23-44. https://doi.org/10.1007/s10978015-9169-5

Crinson, M. (2008). Singapore's moment: Critical regionalism, its colonial roots and profound aftermath. Journal of Architecture, 13(5), 585-605.

https://doi.org/10.1080/13602360802453343

Dafrina, A., Purnama Lisa, N., Siska, D., \& Nurhaiza. (2017). Regionalism of Aceh's Traditional Architecture at Bujang Salim Mosque at Krueng Geeukeuh, Aceh. Proceedings of MICoMS 2017, 93-98. https://doi.org/10.1108/978-1-78756-793-100023

Dahliani, D., Soemarno, I., \& Setijanti, P. (2015). Local Wisdom in Built Environment in Globalization Era. International Journal of Education and Research, 3(6), 157-166.

Daryana, H. A., \& Murwaningrum, D. (2018). Transformasi Musik Arumba: Wujud Hibriditas Yang Meng-global. Panggung, 29(1). https://doi.org/10.26742/panggung.v29i1.814

Eggener, K. L. (2002). Placing resistance: A critique of critical regionalism. Journal of Architectural Education, Vol. 55, pp. 228-237. https://doi.org/10.1162/10464880275365793 2

Faisal, G. (2019). Arsitektur Melayu: Identifikasi Rumah Melayu Lontiak Suku Majo Kampar. Langkau Betang: Jurnal Arsitektur, 6(1), 1. https://doi.org/10.26418/lantang.v6i1.31007

Fatimah, S., Binti, T., Abd, H., Kosman, K. A., Kejuruteraan, F., \& Bina, A. (2018). The serambi of negeri sembilan traditional malay house as a multifungsional space - role in custom (ADAT). 17(2017), 2018.

Frampton, K. (1983). Towards a Critical Regionalism: Six points for an architecture of resistance. Anti-Aesthetic. Essays on Postmodern Culture.

Haggerty, M. (2017). A Tropicalist Turn: Architectural Perspectives on Regionalism from Housing in Dhaka. Fabrications, 27(2), 231-258.

https://doi.org/10.1080/10331867.2017.1296 315

Harrison, P. (1995). Changing Cities: Global Economics , Urban Restructuring and Planning Response. Transformation, 28, 3550.

Harwati, L. N. (2013). Preserving Local Culture in the Globalization Era through Merti Bumi: A Project Report. Asian Journal of Literature, Culture and Society, 7(2).

Hibbard, D., Mason, G., \& Weitze, K. (2010). Hart Wood: Architectural Regionalism in Hawaii. Honolulu: University of Hawaii Press.

Hidayatun, Maria I. (2018). Jatidiri Arsitektur Indonesia: Regionalisme dalam Konsep Bhinneka Tunggal Ika. In P. Pratikno (Ed.), Ebook. Yogyakarta: Penerbit K-Media.

Hidayatun, Maria I, Prijotomo, J., \& Rachmawati, M. (2013). Nilai-nilai Kesetempatan dan Kesemestaan dalam Regionalisme Arsitektur di Indonesia. SEMINAR NASIONAL SCAN\#4:2013 "Stone, Steel, and Straw" Building Materials and Sustainable Environment.

https://doi.org/10.1016/j.resconrec.2011.06.0 07

Hidayatun, Maria I, Prijotomo, J., \& Rachmawati, M. (2014). Arsitektur Nusantara sebagai Dasar Pembentuk Regionalisme Arsitektur Indonesia. Seminar Rumah Tradisional Transformasi Nilai-Nilai Tradisional Dalam Arsitektur Masa Kini, 1, 1-9.

Hidayatun, Maria Immaculata, Prijotomo, J., \& Rachmawati, M. (2012). Regionality and Regionalism in Architectural Views. Journal of Basic and Applied Scientific Research, 2(7), 7147-7152.

Holden, R. J., \& Valdez, R. S. (2019). 2019 Town Hall on Human Factors and Ergonomics for Patient Work. Proceedings of the Human Factors and Ergonomics Society Annual Meeting, 63(1), 725-728. https://doi.org/10.1177/1071181319631539

Jashari-Kajtazi, T., \& Jakupi, A. (2017). Interpretation of architectural identity through landmark architecture: The case of Prishtina, Kosovo from the 1970 s to the 1980s. Frontiers of Architectural Research, 6(4), 480-486.

https://doi.org/10.1016/j.foar.2017.09.002 
Khairanisa, F., Setyawan, H., \& Farkhan, A. (2017). Sentra Mebel Sebagai Destinasi Wisata Dengan Pendekatan Arsitektur Regionalisme Di Juwiring, Klaten. Arsitektura, 14(2). https://doi.org/10.20961/arst.v14i2.9088

Khelifa-Rouaissia, S., \& Boulkroune, H. (2017). The Architecture of the Town Halls of the French Colonial Period in Algeria: The First Half of Nineteenth Century. International Journal of Historical Archaeology, 21(2), 420-432. https://doi.org/10.1007/s10761016-0352-7

Kristina, D., \& Tyas, W. P. (2018). Pelibatan Masyarakat Dalam Penataan Permukiman Kampung Nelayan. Jurnal Pengembangan Kota, 6(1), 35. https://doi.org/10.14710/jpk.6.1.35-44

Kuśnierz-Krupa, D., Figurska-Dudek, J., \& Malczewska, J. (2019). Architectonic heritage (Town hall and palace) in the town of Dukla in the Podkarpacie Region. Wiadomosci Konserwatorskie, 2019(57), 30-37. https://doi.org/10.17425/WK57DUKLA

Lake, R. C., Arinto, F. X. E., Purbadi, Y. D., Dwisusanto, Y. B., Bin Toni, E. A., \& Rayawulan, R. M. (2020). Architecture expression: Synthesized architectural expressions in Mayor's office building of Kupang City. Local Wisdom : Jurnal Ilmiah Kajian Kearifan Lokal, 12(2), 135-147. https://doi.org/10.26905/lw.v12i2.4302

LE, D. V. (2018). Vietnamese Folk Architecture: Regional Architecture based on Climatic Adaptation. Design Journal, 21(6), 855-862. https://doi.org/10.1080/14606925.2018.1525 016

Lefaivre, L., \& Tzonis, A. (2004). Critical regionalism: architecture and identity in a globalized world. Choice Reviews Online, 41(08), 41-4450-41-4450. https://doi.org/10.5860/choice.41-4450

Loanoto, S. Y. (2019). Wastu Citra as an Indonesia Regionalism Local Wisdom. International Journal of Architecture and Urbanism, 3(1), 69-80. https://doi.org/10.32734/ijau.v3i1.779

Malik, S., \& Hassan, K. A. K. (2019). An investigation of house designs in Lahore: Transformation of residential architecture from traditional to modern. Journal of Design and Built Environment, 19(1), 49-59. https://doi.org/10.22452/jdbe.vol19no1.5

Marshall, A. H., \& Hyde, J. R. (1982). The acoustical design of Wellington Town Hall. The Journal of the Acoustical Society of
America, $\quad 71(\mathrm{~S} 1), \quad$ S60-S60. https://doi.org/10.1121/1.2019481

Maulana, S., \& Suswati, S. (2014). Interpretasi Elemen Vernakular pada Tata Ruang Kawasan sebagai Implementasi Regionalisme Kritis. Jurnal Tataloka, 16(1), 29. https://doi.org/10.14710/tataloka.16.1.29-36

McHugh, M. (2020). A Cross-Disciplinary Approach to the Conservation of Manchester Town Hall. Studies in Conservation, Vol. 65, pp. 221-224. https://doi.org/10.1080/00393630.2020.1774 103

Mentayani, I. (2008). Jejak Hubungan Arsitektur Tradisional Suku Banjar Dan Suku Bakumpai. DIMENSI Jurnal Teknik Arsitektur, 36(1), 5464.

Michael, A., Hadjichristos, C., Bougiatioti, F., \& Oikonomou, A. (2010). Bioclimatic parameters in the design of contemporary buildings: The proposal for the new town hall of Deryneia, Cyprus. Renewable Energy and Power Quality Journal, 1(8), 22-26. https://doi.org/10.24084/repqj08.210

Moore, S. (2007). Technology, place, and nonmodern regionalism. Architectural Regionalism: Collected Writings on Place, Identity, Modernity, and Tradition, (January 2010), 433-437.

Nur, T. K. H. M., Antariksa, \& Sari, N. (2009). Pelestarian Pola Permukiman Masyarakat Using Di Desa Kemiren Kabupaten Banyuwangi (Preservation of Using Community Settlement Patterns in Kemiren Village, Banyuwangi Regency). Arsitektur EJournal, 2(3), 191-207.

Nurdiah, E. A., \& Hariyanto, A. D. (2013). Struktur Rangka Atap Rumah Tradisional Sumba (Roof Structure of a Traditional Sumba House). Semnas Reinterpretasi Identitas Arsitektur Nusantara, 117-124. Denpasar: Semnas Reinterpretasi Identitas Arsitektur Nusantara.

Nurkarismaya, Siahaan, N. M., \& Eddy, F. (2020). The influence of acehnese traditional architecture on government building (Case study: Mayor office architecture, Lhokseumawe). IOP Conference Series: Earth and Environmental Science, 452(1). https://doi.org/10.1088/17551315/452/1/012001

Olgyay, V. (2015). Design with Climate: Bioclimatic Approach to Architectural Regionalism. In Ebook. New Jersey: Princeton University Press.

Paiva Henrique, K. (2013). Modernity and 
Continuity: Alternatives to Instant Tradition in Contemporary Brazilian Architecture. Spaces \& Flows: An International Journal of Urban \& Extra Urban Studies, 3(4), 103-112. Retrieved from https://ezp.lib.unimelb.edu.au/login?url=https ://search.ebscohost.com/login.aspx?direct=tru $\mathrm{e} \& \mathrm{db}=\operatorname{sih} \& \mathrm{AN}=91804562 \&$ scope $=$ site

Perrons, D. (2004). Globalization and Social Change: People and places in a divided world. In https://doi.org/10.4324/9780203646434

Peterson, A., Mcalpine, C. A., Ward, D., \& Rayner, S. (2007). New regionalism and nature conservation: Lessons from South East Queensland, Australia. Landscape and Urban Planning, 82(3), 132-144. https://doi.org/10.1016/j.landurbplan.2007.02 .003

Poon, S. T. F. (2019). Contribution of Ecological Design to Critical Regionalism: Analysing Sustainability Effectiveness in Vernacular Urban Building. ISPRS Annals of the Photogrammetry, Remote Sensing and Spatial Information Sciences, 4(4/W9), 103-109. https://doi.org/10.5194/isprs-annals-IV-4W9-103-2019

Pour, F. H. (2015). The Theoretical Inapplicability of Regionalism to Analysing Architectural Aspects of Islamic Shrines in Iran in the Last Two Centuries The Theoretical Inapplicability of Regionalism to Analysing Architectural Aspects of Islamic Shrines in Iran in the Last. A Gateway to Melbourne's Research Publications, (September 2013), 1-10.

Purbadi, Y. D. (2010). Tata Suku dan Tata Spasial pada Arsitektur Permukiman Suku Dawan di Desa Kaenbaun di Pulau Timor (disertasi, tidak dipublikasikan, Universitas Gadjah Mada).

https://doi.org/10.13140/RG.2.2.18372.32640

Purbadi, Y. D. (2017). Continuity and Change dalam Arsitektur Vernakular: Kajian Fenomena Lopo di Desa Kaenbaun (Continuity and Change in Vernacular Architecture: Study of the Lopo Phenomenon in Kaenbaun Village). Seminar Nasional Riset Dan Teknologi Terapan 2017 (Ritektra 2017), 69-82.

Purbadi, Y. D. (2018). Catatan Lapangan pada Observasi Rumah Tradisional Sumba 2018. Yogyakarta: Laboratorium Perencanaan Perancangan Lingkungan dan Kawasan.

Purbadi, Y. D. (2019). Arsitektur Etnis sebagai Ibu Pertiwi Arsitektur di Indonesia Kini dan
Masa Depan (Ethnic Architecture as Ibu Pertiwi of Architecture in Indonesia Now and the Future). Simposium Perkembangan Arsitektur Nusantara 2. Malang: Laboratorium Arsitektur Nusantara, Jurusan Arsitektur, Universitas Brawijaya.

Rakhman, A. (2015). Makna Simbolis Ornamen Rumah Limas Palembang. https://doi.org/10.1145/3132847.3132886

Rakhmawati, Y. (2017). Hibriditas New Media Komunikasi Dan Homogenisasi Budaya. Jurnal Komunikasi, 10(2), 117. https://doi.org/10.21107/ilkom.v10i2.2516

Rohmawati, A. S., Roychansyah, M. S., Hatmoko, A. U., Arsitektur, P. S., Teknik, F., \& Mada, U. G. (2007). Identifikasi Pendekatan Regionalisme Dalam Arsitektur Hotel Kontemporer Di Yogyakarta. Seminar Nasional "Kearifan Lokal Dalam Keberagaman Untuk Pembangunan Indonesia “, 43-50. Medan: Departemen Arsitektur, Fakultas Teknik, Universitas Sumatera Utara.

Salura, P., Clarissa, S., \& Lake, R. C. (2020a). Reflecting the spirit of modern-indonesia through architecture: The icono-symbolical meanings of jengki architectural style case studies: Bandung polytechnic of health building and bumi sangkuriang meeting hall in bandung, west java, indonesia. Journal of Design and Built Environment, 20(2), 13-26.

Salura, P., Clarissa, S., \& Lake, R. C. (2020b). The application of sundanese vernacular concept to the design of modern building Case study: Aula barat (west hall) of Bandung Institute of Technology, West Java, Indonesia. Journal of Design and Built Environment, 20(1), 1-12.

Shahedi, B. (2012). Users ' Perceptions of Aesthetic Design Approach of Safavid. Journal of Design and Built Environment, 10, 114-117.

Silmi, A., Suparno, S., \& Paramita, D. S. P. (2017). Malang Ceramic Craft Center Dengan Pendekatan Arsitektur Regionalisme Di Kota Malang. Arsitektura, 13(1). https://doi.org/10.20961/arst.v13i1.15572

Skelton, T., \& Allen, T. (1999). Culture and Global Change. In Ebook. https://doi.org/10.4324/9780203984123

Spivak, G. C. (2014). Nationalism and the imagination. Critical Studies, 37(d), 31-55. https://doi.org/10.1215/1089201x-1426818

Subroto, T. Y. W. (2019). Koeksistensi alam dan budaya dalam arsitektur. ARTEKS: Jurnal Teknik Arsitektur, 3(2). 
https://doi.org/10.30822/arteks.v3i2.60

Tanrim, C. F., Stefani, M., Cynthia, Stefanie, W., \& Wijaya, J. (2014). Sistem Struktur Rumah Adat Barat Rattenggaro. Prosiding Temu Ilmiah IPLBI, 7-12. Retrieved from http://temuilmiah.iplbi.or.id/wpcontent/uploads/2015/01/TI2014-C-p007012-Sistem-Struktur-Rumah-Adat-BaratRattenggaro.pdf

Tuan, A., Song, N., Truong, H., Verne, D. P. J., \& Innovantes, T. (2019). Studies on sustainable features of vernacular architecture in different regions across the world: A comprehensive synthesis and evaluation. Frontiers of Architectural Research, (xxxx). https://doi.org/10.1016/j.foar.2019.07.006

Valand, M. S. (2011). Between organisation and architecture: End-user participation in design. International Journal of Work Organisation and Emotion, 4(1), 42-60. https://doi.org/10.1504/IJWOE.2011.041530

Van Leeuwen, T. (2005). Introducing Social Semiotics: An Introductory Textbook. Retrieved from http://www.amazon.com/Introducing-SocialSemiotics-IntroductoryTextbook/dp/0415249449/ref=sr_1_7?s=boo $\mathrm{ks} \& \mathrm{ie}=\mathrm{UTF} \& \& \mathrm{qid}=1411401936 \mathrm{\&} \mathrm{sr}=1-$ 7\&keywords $=$ Van + Leeuwen $\% 2 \mathrm{C}+2005$

Voll, H., \& Seinre, E. (2012). Cooling demand and daylight in the new Tallinn Town Hall buildings the influence of facade design. Energy Procedia, 30, 1243-1249. https://doi.org/10.1016/j.egypro.2012.11.137

Wakim, M. (2018). Sasadu: Arsitektur Tradisional Jailolo Halmahera Barat. Patanjala: Jurnal Penelitian Sejarah Dan Budaya, $7(1)$, 1. https://doi.org/10.30959/patanjala.v7i1.78

Widodo, J. (2019). Human, Nature, And Architecture. ARTEKS : Jurnal Teknik Arsitektur, 3(2), 145-148. https://doi.org/10.30822/arteks.v3i2.65

Yang, S.-H. (2009). Regionalism Architecture in Jeju Island - A Critical Review of its Trends and Characteristics, since 1950's -. Journal of Architectural History, 18(6), 7-22.

Yeang, K. (1987). Tropical Urban Regionalism: Building in a South-East Asian city. Singapore: Concept Media.

Yuwono, S., \& Wardiningsih, S. (2016). Mempertahankan Keberadaan Kampung Di Tengah-Tengah Kawasan Modern Jakarta. NALARs, $\quad 15(1), \quad 73$ https://doi.org/10.24853/nalars.15.1.73-80 